\title{
Immunohistochemical Expression of p63, Epidermal Growth Factor Receptor (EGFR) and Notch-1 in Radicular Cysts, Dentigerous Cysts and Keratocystic Odontogenic Tumors
}

\author{
Cláudia Kallás GONÇALVES \\ Eduardo Rodrigues FREGNANI \\ Jorge Esquiche LEON \\ Yara Teresinha Corrêa SILVA-SOUSA \\ Danyel Elias da Cruz PEREZ
}

\begin{abstract}
Department of Clinical and Preventive Dentistry, Oral Pathology Section, Dental School, UFPE - Federal University of Pernambuco, Recife, PE, Brazil
\end{abstract}

\begin{abstract}
The aim of this study was to assess the immunohistochemical expression of p63 protein, epidermal growth factor receptor (EGFR) and Notch-1 in the epithelial lining of radicular cysts (RC), dentigerous cysts (DC) and keratocystic odontogenic tumors (KOT). For this study, 35 RC, 22 DC and 17 KOT were used. The clinical and epidemiological data were collected from the patient charts filed in the Oral Pathology Laboratory, University of Ribeirão Preto, Brazil. Immunohistochemical reactions against the p63, EGFR and Notch-1 were performed in 3- $\mu \mathrm{m}$-thick histological sections. The slides were evaluated according to the following criteria: negative: $<5 \%$ of positive cells, low expression: $5-50 \%$ of positive cells, and high expression: $>50 \%$ of positive cells. Moreover, the intensity of EGFR and Notch-1 expressions was also evaluated. Fisher's exact test and Spearman's correlation coefficients were used for statistical analysis, considering a significance level of 5\%. Almost all cases demonstrated p63, EGFR and Notch-1 expressions. The p63 expression was significantly higher in KOT $(\mathrm{p}<0.001)$. Positive correlation between these immunomarkers was observed. These findings suggest the participation of p63, EGFR and Notch-1 in the development, maintenance and integrity of cystic odontogenic epithelial lining, favoring lesion persistence. The high expression of p63 in KOT suggests that it may be related to their more aggressive biological behavior and marked tendency to recurrence.
\end{abstract}

Key Words: radicular cyst, dentigerous cyst, keratocystic odontogenic tumor, p63, EGFR, notch signaling.

\section{INTRODUCTION}

The p63 protein plays an essential role in epithelial development and the proliferation of limb and craniofacial-structures. Studies with murine model have revealed that 163 knockout-mice display profound defects in differentiation of tissues with stratified epithelium, including skin, oral cavity and esophagus. Moreover, these animals did not develop teeth, hair follicles and salivary, lachrymal and mammary glands (1). In human oral mucosa, p63 is chiefly restricted to basal and parabasal layers of the normal epithelium. As the odontogenic cystic lesions are essentially of epithelial origin, the $\mathrm{p} 63$ protein may be important in the growth and progression of these lesions. However, only one study evaluated the $\mathrm{p} 63$ expression in odontogenic cystic lesions, which detected positivity more intense and diffuse in the epithelial lining of keratocystic odontogenic tumor when compared with radicular and dentigerous cysts (2).

The epidermal growth factor receptor (EGFR) is localized on the surface membranes of many cell types and is mostly involved in cell proliferation (3). Immunohistochemical analysis has shown that EGFR is frequently present in the epithelial elements of human tooth germ as well as cystic odontogenic lesions and

Correspondence: Prof. Dr. Danyel Elias da Cruz Perez, Universidade Federal de Pernambuco, Curso de Odontologia, Área de Patologia Oral, Avenida Prof. Moraes Rego, 1235, Cidade Universitária, 50670-901 Recife, PE, Brasil. Tel: +55-81-2126-7510. Fax: +55-81-2126-8338. e-mail: danyel perez@ufpe.br 
odontogenic tumors, thus implicating its participation during normal odontogenesis and development of these lesions $(4,5)$.

Notch is an important signaling system composed by four receptors (Notch 1-4) and 5 ligands (Delta 1, Delta 3, Delta 4, Jagged 1 and Jagged 2), which regulate embryonic development and adult tissue homeostasis (6). Notch signaling pathway plays an essential role during odontogenesis, neurogenesis, hematopoiesis, vasculogenesis and keratinocyte growth/differentiation (7-9). Aberrant Notch function has been associated with a wide range of developmental disorders and neoplasms $(10,11)$. Expression of Notch receptors and ligands in tooth germs and odontogenic tumors suggests that Notch signaling might control the cell differentiation and proliferation of normal and neoplastic odontogenic epithelium (7). However, Notch expression in cystic odontogenic lesions is scarcely studied. Recently, Meliou et al. (6) observed abundant Notch expression in the epithelial lining of radicular cysts, suggesting an involvement of this pathway in the growth of these cysts.

Because the p63, EGFR and Notch receptors are involved in the development and differentiation of odontogenic epithelium, the aim of this study was to evaluate the immunohistochemical expression of p63, EGFR, and Notch-1 receptor in radicular cysts (RC), dentigerous cysts (DC) and keratocystic odontogenic tumors (KOT).

\section{MATERIAL AND METHODS}

Seventy-four cases of odontogenic cystic lesions ( 35 radicular cysts, 22 dentigerous cysts and 17 keratocystic odontogenic tumors) from the files of the Oral Pathology Laboratory, Dental School, University of Ribeirão Preto, Ribeirão Preto, SP, Brazil, from the period between 1994 to 2006, were selected for this study. Clinical and epidemiological data, such as age, gender and site of the lesion, were collected from the patient charts filed in the Oral Pathology Laboratory. All cases were reviewed histologically in slides stained with hematoxylin and eosin and the inflammatory reaction eventually present in the fibrous capsule was classified as mild (foci of inflammatory cells) or severe (diffuse inflammatory reaction). This study was approved by the institutional Ethics Committee (Process \#085/06).

Immunohistochemical reactions against p63 (mouse anti-human monoclonal antibody, clone 4A4, dilution 1:2000; ThermoScientific, San Jose, CA, USA),
EGFR (mouse anti-human monoclonal antibody, clone EGFR-25, dilution 1:100; Abcam, Cambridge, UK) and Notch-1 (mouse anti-human monoclonal antibody, clone A6, dilution 1:100; Abcam) were carried out in $3-\mu \mathrm{m}$-thick histological sections. Antigen retrieval was performed in a pressure cooker for 4 min using a 10 mmol L-1 citrate buffer ( $\mathrm{pH}$ 6.0). Histological sections were quenched of endogenous peroxidase with 3\% aqueous hydrogen peroxidase (Merck, Rio de Janeiro, RJ, Brazil) for $20 \mathrm{~min}$ at room temperature, followed by a washing with $10 \mathrm{mmol} \mathrm{L}^{-1}$ phosphate-buffered saline ( $\mathrm{pH}$ 7.4) for $5 \mathrm{~min}$. Incubations with the primary antibody were performed for $18 \mathrm{~h}$ at $4^{\circ} \mathrm{C}$. Next, the tissue sections were incubated with Post Primary Block for $30 \mathrm{~min}$ at $37^{\circ} \mathrm{C}$ (NovoLink Max Polymer, Novocastra, Newcastle, UK), followed by application of diaminobenzidine as the chromogen (Dako, Glostrup, Denmark). Slides were counterstained with Harris hematoxylin, mounted and analyzed by two previously calibrated oral pathologists. Positive (normal skin for p63, large bowel for EGFR and placenta for Notch-1) and negative (omission of primary antibody) controls were included in all reactions.

The p63, EGFR and Notch-1 expressions were evaluated in the cystic epithelial lining. For EGFR, the cells considered positive were those with membrane and/or cytoplasmic markings; for Notch-1, the cells with nuclear and/or cytoplasmic marking were considered positive and for $\mathrm{p} 63$, the cells considered positive were those with nuclear staining pattern only. The percentage of positive cells in 10 high-power fields was evaluated, adopting the following criteria: negative: $5 \%$ of positive cells; low expression: $5-50 \%$ of positive cells, and high expression: $>50 \%$ of positive cells. In addition, for EGFR and Notch-1, the intensity of positive cells was also assessed as weak intensity and strong intensity, considering the cases that presented cells with pale brown staining as showing weak intensity of expression, and the cases with dense brown staining as strong. The evaluators were blinded with respect to the types of cystic lesions during the analysis and the disagreements were discussed until a consensus was reached.

For statistical analysis, the lesions were compared with regard to the expression of the studied antibodies (Fisher's exact test), and to the possible existence of correlation among p63, EGFR and Notch-1 expressions in each cystic lesion (Spearman's correlation coefficients). A significance level of 5\% was adopted for all analyses. 


\section{RESULTS}

\section{Radicular Cysts}

Eighteen cases (51.4\%) showed the cystic wall lined by thin stratified squamous epithelium, whereas the remaining 17 cases $(48.6 \%)$ showed epithelial hyperplasia. The chronic inflammatory reaction in the adjacent connective tissue was classified as severe and mild in 23 (65.7\%) and 12 (34.3\%) cases, respectively.

The immunohistochemical analysis revealed that 32 cases $(91.43 \%)$ of RC presented high positivity for p63 protein in all layers of the epithelial lining. In 2 cases $(6.25 \%)$ that showed hyperplastic epithelium associated with severe inflammation in the fibrous capsule, decreased p63 expression was observed (Fig. 1). All RC cases showed high expression of EGFR in all epithelial cell layers. Out of them, 21 cases $(60 \%)$ presented strong staining intensity, whereas 14 cases (40\%) showed weak staining intensity (Fig. 1). The chronic inflammatory reaction present in the fibrous capsule did not influence the expression of EGFR in the epithelial lining. Similar to EGFR expression, all cases were positive for Notch-1. High expression for Notch-1 was noted in 28 cases $(82.35 \%)$ and 6 cases $(17.65 \%)$ showed low expression. Seventeen cases $(50 \%)$ showed strong staining intensity and 17 presented weak expression intensity (Fig. 1). For Notch-1, one case of RC was excluded because of a significant unspecific reaction.

\section{Dentigerous Cysts}

All cases of DC were positive for p63 in all layers of the epithelial lining, with 16 cases $(72.73 \%)$ showing high positivity and 6 cases (27.27\%) showing low positivity (Fig. 2).

Similar to p63 expression, all analyzed cases were positive for EGFR in all cell layers. Twenty cases (95.24\%) showed high positivity and 1 case $(4.76 \%)$ low positivity (Fig. 2). Regarding the expression intensity, 16 cases $(76.19 \%)$ presented strong staining intensity, whereas 5 cases $(23.81 \%)$ showed weak expression intensity. After immunohistochemical analysis, one case of DC did not present sufficient tissue for analysis.

All cases showed high positivity for Notch-1 in all epithelial layers, with 17 cases $(77.27 \%$ ) presenting strong staining intensity and $5(22.73 \%)$ weak intensity (Fig. 2).

\section{Keratocystic Odontogenic Tumors}

All cases of KOT showed high p63 expression in all layers of the epithelial lining (Fig. 3). One case was not evaluated because of the small amount of tissue.

The EGFR immunoexpression was observed in 16 cases of KOT (94.12\%) (Fig. 3). Regarding the expression intensity, 12 cases $(75 \%)$ showed strong expression intensity for EGFR and 4 cases (25\%) weak
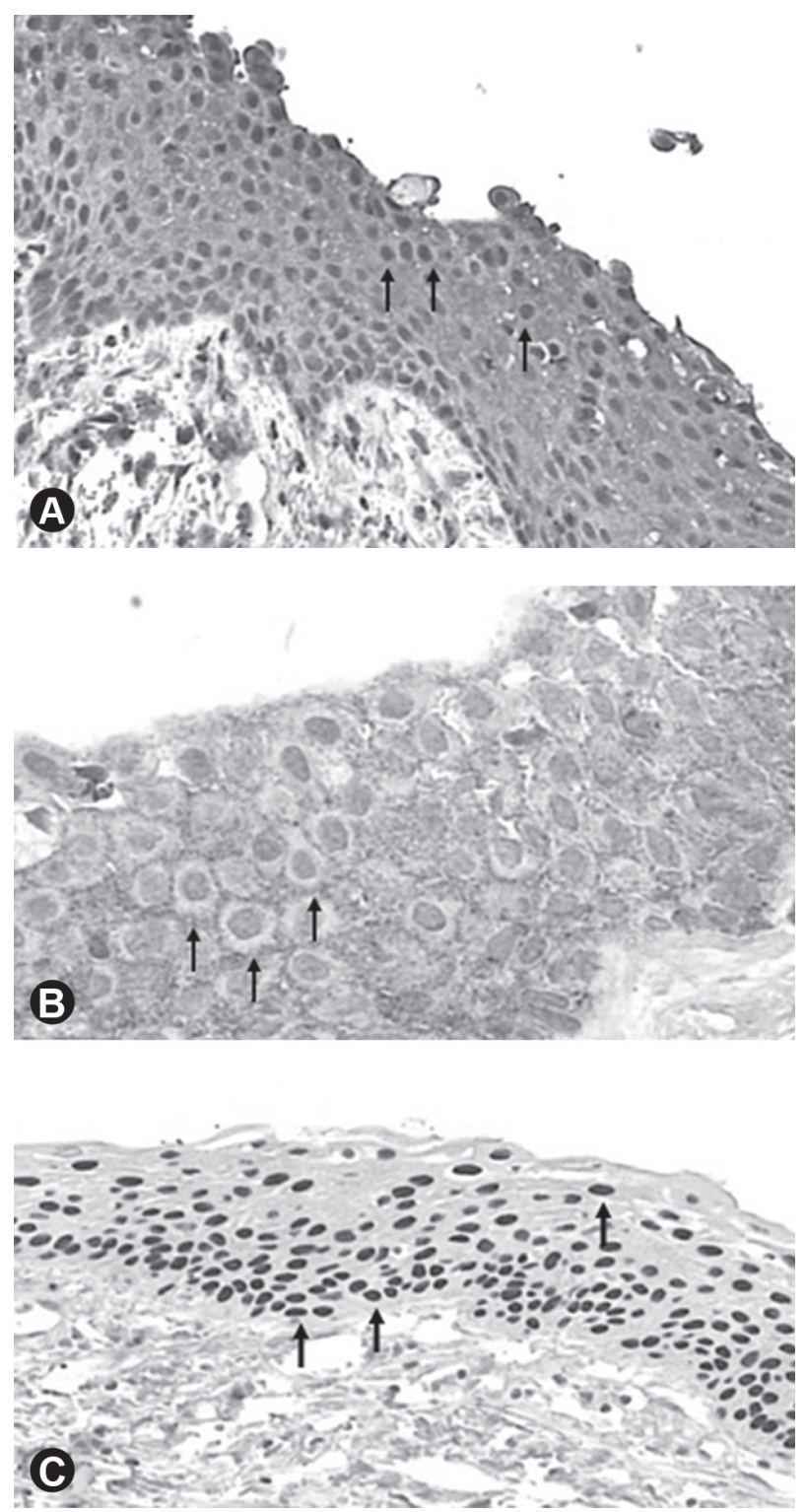

Figure 1. Radicular cyst. A: High and strong expression intensity of Notch-1 in the epithelial lining $(\times 100)$; B: High and strong staining intensity of EGFR in the cystic epithelial lining $(\times 200)$; $\mathrm{C}$ : High expression of $\mathrm{p} 63$ in all layers of the cystic epithelial lining $(\times 100)$. 
staining intensity.

All evaluated KOT cases were positive for Notch-1, with 12 cases (75\%) showing high positivity and 4 cases $(25 \%)$ showing low positivity (Fig. 3). From these cases, 14 (87.5\%) presented strong staining intensity, whereas 2 cases $(12.5 \%)$ showed weak intensity. One KOT case was not evaluated because of significant unspecific reaction.
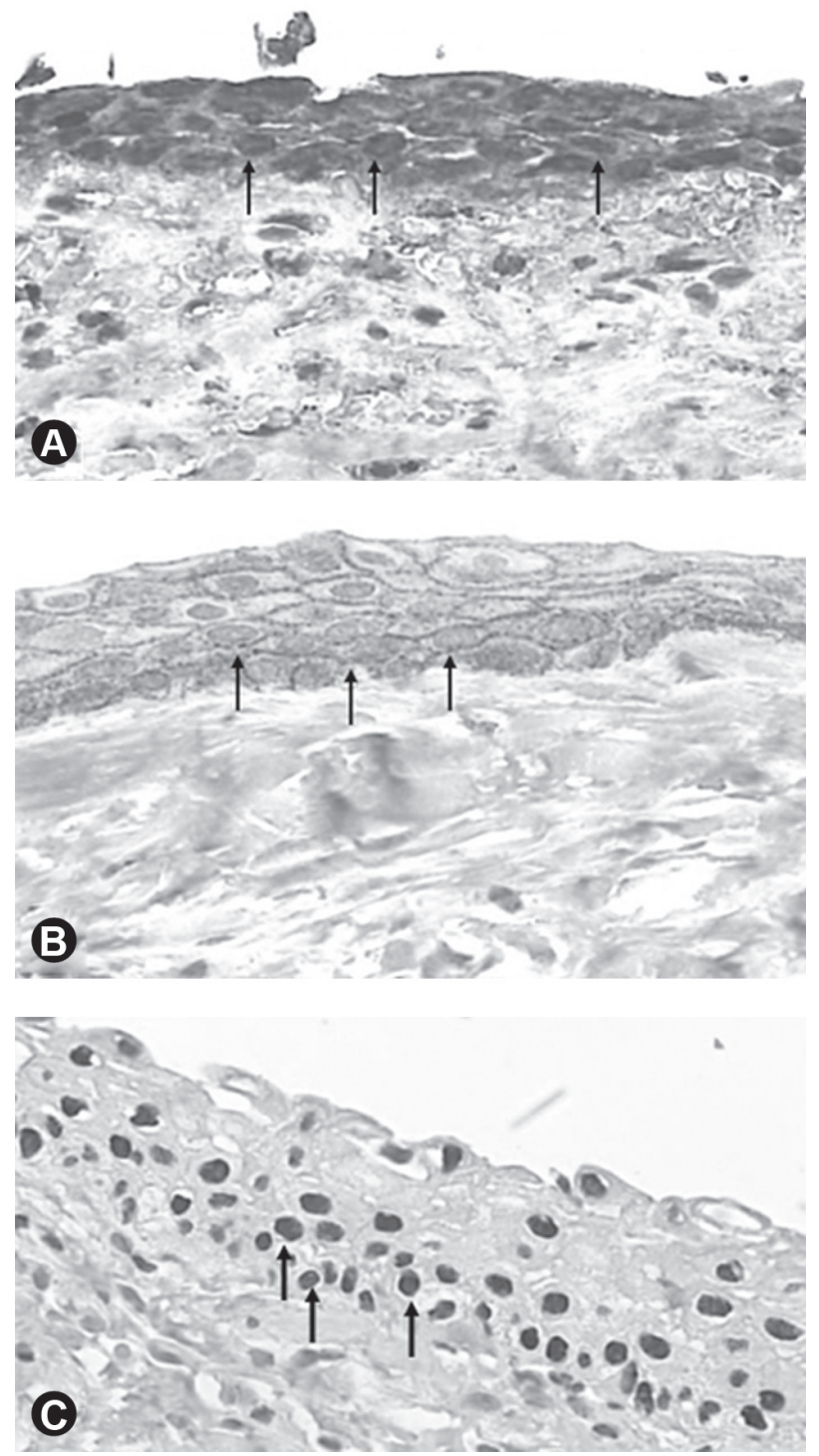

Figure 2. Dentigerous cyst. A: High and strong expression intensity of Notch-1 in the cystic epithelial lining $(\times 100)$; B: High and strong staining intensity of EGFR in the epithelial lining $(\times 100)$; $\mathrm{C}$ : High expression of $\mathrm{p} 63$ in all layers of the cystic epithelial lining $(\times 100)$.

\section{Statistical Analysis}

KOT showed significantly higher positivity for p63 $(\mathrm{p}<0.001)$ than RC and DC. However, no significant difference in the expression $(\mathrm{p}=0.1)$ and expression intensity of EGFR $(\mathrm{p}=0.2)$ was observed among the lesions. In the same way, no differences in the expression $(\mathrm{p}=0.1)$ and expression intensity $(\mathrm{p}=0.08)$ of Notch- 1


Figure 3. Keratocystic odontogenic tumor. A: High and strong expression intensity of Notch-1 in the epithelial lining of keratocystic odontogenic tumor $(\times 100)$; B: High and strong expression intensity of EGFR in the cystic epithelial lining $(\times 200)$; C: High $p 63$ expression in all layers of the cystic epithelial lining $(\times 100)$. 
were observed (Table 1).

In RC and DC, positive correlation was observed between the expression and staining intensity of EGFR $(p<0.001)$, or expression and staining intensity of Notch-1 $(p<0.001)$. In both lesions, positive correlation was found between expression and staining intensity of EGFR, expression and staining intensity of Notch-1 and p63 expression $(p<0.001)$. In KOT, there was positive correlation between $\mathrm{p} 63$ expression and the expression and staining intensity of EGFR $(\mathrm{p}<0.001)$ as well as between expression and staining intensity of Notch-1 $(p<0.001)$. Moreover, correlation was observed between expression and staining intensity of EGFR $(\mathrm{p}=0.03)$ as well as between expression and staining intensity of Notch-1 $(\mathrm{p}=0.005)$.

Table 1. Comparative analysis of the expression and staining intensity patterns for p63, EGFR, and Notch-1 in odontogenic cystic lesions.

\begin{tabular}{|c|c|c|c|c|}
\hline \multirow[b]{2}{*}{ Variables } & \multicolumn{3}{|c|}{ Lesions } & \multirow[b]{2}{*}{$\mathrm{p}$ value } \\
\hline & $\begin{array}{c}\mathrm{RC} \\
\mathrm{n}=35(\%)\end{array}$ & $\begin{array}{c}\text { DC } \\
n=22(\%)\end{array}$ & $\begin{array}{c}\text { KOT } \\
\mathrm{n}=17(\%)\end{array}$ & \\
\hline \multicolumn{5}{|c|}{ p63 expression } \\
\hline Negative & $3(8.57)$ & $0(0.0)$ & $0(0.0)$ & $<0.001$ \\
\hline Low & $0(0.0)$ & $6(27.27)$ & $0(0.0)$ & \\
\hline High & $32(91.43)$ & $16(72.73)$ & $16(100)^{*}$ & \\
\hline \multicolumn{5}{|c|}{ EGFR expression } \\
\hline Negative & $0(0.0)$ & $0(0.0)$ & $1(5.88)$ & 0.1 \\
\hline Low & $0(0.0)$ & $1(4.76)$ & $0(0.0)$ & \\
\hline High & $35(100)$ & $20(95.24)^{*}$ & $16(94.12)$ & \\
\hline \multicolumn{5}{|c|}{ EGFR intensity } \\
\hline Weak & $14(40.0)$ & $5(23.81)$ & $4(25.0)$ & 0.2 \\
\hline Strong & $21(60.0)$ & $16(76.19)^{*}$ & $12(75.0)^{*}$ & \\
\hline \multicolumn{5}{|c|}{ Notch-1 expression } \\
\hline Negative & $0(0.0)$ & $0(0.0)$ & $0(0.0)$ & \\
\hline Low & $6(17.65)$ & $0(0.0)$ & $2(12.5)$ & 0.1 \\
\hline High & $28(82.35)^{*}$ & $22(100)$ & $14(87.5)^{*}$ & \\
\hline \multicolumn{5}{|c|}{ Notch-1 intensity } \\
\hline Weak & $17(50.0)$ & $5(22.73)$ & $4(25.0)$ & 0.08 \\
\hline Strong & $17(50.0)$ & 17 (77.27) & $12(75.0)$ & \\
\hline
\end{tabular}

RC: radicular cyst; DC: dentigerous cyst; KOT: keratocystic odontogenic tumor. *One case was not available.

\section{DISCUSSION}

Recentstudieshavefocused on the tiopathogenesis of chronic periapical lesions, odontogenic cysts and tumors, using immunohistochemistry to investigate the role of cytokines, growth factors, cellular differentiation factors, tumor suppressor genes and oncogenes in the initiation, development, and progression of these lesions $(4,6,12-17)$.

In this study, most of RC and DC cases and all KOT cases showed high positivity for $\mathrm{p} 63$ protein in all cell layers. Lo Muzio et al. (2) observed that the positivity for $\mathrm{p} 63$ in $\mathrm{RC}$ and $\mathrm{DC}$ was restricted to basal and parabasal layers of the cystic epithelial lining, whereas in KOT the positivity was more evident in the intermediate and superficial layers. These results are similar to the present study and may probably be associated with a disturbance in cellular cycle control, leading to a higher intrinsic growth potential, which could explain the more infiltrative and aggressive growth and higher rates of recurrence observed in KOT. Interestingly, in $\mathrm{RC}$, the epithelium adjacent to regions with severe inflammatory reaction presented diminished p63 expression. This finding suggests that the alterations caused by the inflammatory cells in the epithelial lining contributed to decrease the expression of that protein.

Cell proliferation has been associated with growth factors such as epidermal growth factor (EGF), transforming growth factor (TGF) and their receptors. These growth factors may trigger the process of cell proliferation through a cascade of protein phosphorylation, allowing the signs of proliferation be received, translated and transmitted to the cell nucleus (18). In the current study, only 1 KOT case was negative for EGFR, similar as observed by Clark et al. (19). Likewise, assessing the intensity of EGFR expression, the percentage was similar for all studied odontogenic cystic lesions. Thus, it is assumed that the epithelium of these cystic lesions 
is capable of proliferation mediated by EGFR and that this is an important factor for maintaining the cystic epithelial lining. Most cases of the current series showed membranous and cytoplasmic staining pattern for EGFR. The immunolocalization of this receptor seems to be important in the speed of the cellular response to proliferation stimulus. In cases where EGFR is restricted to the cellular membrane, the response in the presence of a ligand is faster. Otherwise, if the EGFR is internalized into the cytoplasm, the proliferative response to stimulation is diminished. If EGFR is observed concurrently in the membrane and cytoplasm, as in this study, the response of the cells to a proliferative stimulus is similar to a physiological response type (20).

In this study, all cases studied were positive for Notch-1. Additionally, there was a greater intensity of expression for Notch-1 in DC and KOT compared with RC. However, the difference was not significant. The Notch signaling system appears to be important in maintaining normal epithelial tissue. Notch-1 triggers differentiation and inhibits growth of human keratinocytes in vitro. In the odontogenic tissues, the activation of the Notch signaling may inhibit the differentiation of pulp stem cells into odontoblasts (21), indicating distinct roles of this pathway depending on the analyzed tissue. Genetic deletion of the Notch system in human keratinocytes is sufficient, along with the activation of the ras gene to cause aggressive squamous cell carcinomas (22). Kumamoto and Ohki (7) found similar levels of Notch-1 expression in tooth germs and neoplastic cells in ameloblastoma. These findings show that despite accumulated information concerning the Notch signaling in cell fate determination and differentiation, the molecular mechanisms through which the Notch signaling participates in oncogenesis is complex. The Notch proteins appear to have dual opposing properties resulting in a net oncogenic or oncosuppressive function depending on the tumor cells (23). In this context, in the present study and as previously demonstrated in odontogenic tumors (7), Notch-1 displayed high expression levels in DC and KOT, followed by RC, suggesting that overactivation of the Notch pathway occurs in these cystic odontogenic lesions.

Several growth factors and other endogenous regulator mediators have been identified in $\mathrm{RC}, \mathrm{DC}$ and $\operatorname{KOT}(3-5,12,13,15)$. The association of these mediators with the Notch-1 expression might induce the epithelial cell proliferation, with consequent growth of the lesions. Another important property of Notch-1 is the antiapoptotic action in T cells. Thus, Meliou et al. (6) hypothesized that activation of Notch pathway might have antiapoptotic effect in epithelial cells and contribute to the preservation of the cystic lining epithelium. Particularly in RC, Meliou et al. (6) observed that Notch pathway is an active downstream in the epithelial lining of $\mathrm{RC}$, indicating that this pathway is involved in the growth and expansion of this lesion. Further studies will be necessary to determine the exact role of Notchmediated intracellular signaling in odontogenic cystic lesions development.

The positive correlation and co-expression of p63, EGFR and Notch-1 in all the lesions is one more fact that suggests the importance of these proteins in the development and persistence of odontogenic cystic lesions, since all these molecules are essential for differentiation and homeostasis maintenance of epithelial tissue. Thus, the concomitant expression indicates that they can interact and act synergistically to maintain the structure of the cystic epithelial lining.

The present study adds new information regarding the expression of growth factors and proteins involved in cell differentiation, and their possible roles in the studied cystic odontogenic lesions. The identification of Notch-1 in odontogenic cystic lesions, suggests that the Notch system participates in maintaining the integrity of the cystic epithelium, possibly contributing to the persistence of the lesion.

\section{RESUMO}

O objetivo deste estudo foi avaliar a expressão imunoistoquímica da proteína $\mathrm{p} 63$, receptor do fator de crescimento epidérmico (EGFR) e Notch-1 no revestimento epitelial de cistos radiculares (CR), cistos dentígeros (CD) e tumores odontogênicos queratocísticos (TOQ). Para este estudo, 35 CR, 22 CD e 17 TOQ foram utilizados. Os dados clínicos e epidemiológicos foram coletados das fichas dos pacientes arquivadas no Laboratório de Patologia Oral, Universidade de Ribeirão Preto, Brasil. Reações imunoistoquímicas contra p63, EGFR e Notch-1 foram realizadas em cortes histológicos de $3 \mu \mathrm{m}$. As lâminas foram avaliadas de acordo com os seguintes critérios: negativo $<5 \%$ das células positivas, baixa expressão - 5\%-50\% das células positivas e alta expressão $>50 \%$ das células positivas. Além disso, a intensidade de expressão de EGFR e Notch-1 foi também avaliada. Teste exato de Fisher e coeficiente de correlação de Spearman foram usados para análise estatística, considerando um nível de significância de 5\%. Quase todos os casos demonstraram expressão de p63, EGFR e Notch-1. A expressão de p63 foi significativamente maior nos TOQ $(\mathrm{p}<0.001)$. Correlação positiva entre os imunomarcadores foi observada. Esses achados sugerem a participação de p63, EGFR e Notch-1 no desenvolvimento, manutenção e integridade 
do revestimento epitelial cístico, favorecendo a persistência das lesões. A alta expressão de p63 no TOQ sugere que ela pode estar relacionada ao comportamento biológico mais agressivo e marcada tendência a recorrência.

\section{REFERENCES}

1. Chen YK, Hsue SS, Lin LM. Immunohistochemical demonstration of p63 in DMBA-induced hamster buccal pouch squamous cell carcinogenesis. Oral Dis 2003;9:235-240.

2. Lo Muzio L, Santarelli A, Caltabiano R, Rubini C, Pieramici T, Fior L, et al.. p63 expression in odontogenic cysts. Int J Oral Maxillofac Surg 2005;34:668-673.

3. Vered M, Shohat I, Buchner A. Epidermal growth factor receptor expression in ameloblastoma. Oral Oncol 2003;39:138-143.

4. Li TJ, Browne RM, Matthews JB. Immunocytochemical expression of growth factors by odontogenic jaw cysts. Mol Pathol 1997;50:21-27

5. Tanikawa Y, Bawden JW. The immunohistochemical localization of phospholipase $\mathrm{c} \gamma$ and the epidermal growth-factor, plateletderived growth-factor and fibroblast growth-factor receptors in the cells of the rat molar enamel organ during early amelogenesis. Arch Oral Biol 1999;44:771-780.

6. Meliou E, Kerezoudis N, Tosios K, Lafkas D, Kiaris H. Immunohistochemical expression of notch signaling in the lining epithelium of periapical cysts. J Endod 2011;37:176-180.

7. Kumamoto H, Ohki K. Detection of notch signaling molecules in ameloblastomas. J Oral Pathol Med 2008:37:228-234.

8. Rangarajan A, Talora C, Okuyama R, Nicolas M, Mammucari $\mathrm{C}$, Oh $\mathrm{H}$, et al.. Notch signaling is a direct determinant of keratinocyte growth arrest and entry into differentiation. EMBO J 2001;20:3427-3436.

9. Mitsiadis TA, Lardelli M, Lendahl U, Thesleff I. Expression of Notch 1, 2, and 3 is regulated by epithelial-mesenchymal interactions and retinoic acid in the developing mouse tooth and associated with determination of ameloblast cell fate. J Cell Biol 1995; 130:407-418

10. Miele L, Aguet M, Radtke F, Dotto GP. Notch signaling is a direct determinant of keratinocyte growth arrest and entry into differentiation. EMBO J 2001;20:3427-3436.

11. Harper JA, Yuan JS, Tan JB, Visan I, Guidos CJ. Notch signaling in development and disease. Clin Genet 2003;64:461-472.

12. Meghji S, Qureshi W, Henderson B, Harris M. The role of endotoxin and cytokines in the pathogenesis of odontogenic cysts. Arch Oral Biol 1996;41:523-531.
13. Menezes R, Bramante CM, Paiva KBS, Letra A, Carneiro E, Zambuzzi WF et al.. Receptor activator NFkappaB-ligand and osteoprotegerin protein expression in human periapical cysts and granulomas. Oral Surg Oral Med Oral Pathol Oral Radiol Endod 2006;102:404-409.

14. Nadalin MR, Fregnani ER, Silva-Sousa YT, Perez DE. Syndecan-1 (CD138) and Ki-67 expression in odontogenic cystic lesions. Braz Dent J 2011;22:223-229.

15. Lima AC, Fregnani ER, Silva-Sousa YT, da Cruz Perez DE. Parathyroid hormone/parathyroid hormone-related peptide receptor 1 expression in odontogenic cystic lesions. Int Endod J 2012;45:209-214.

16. Lima SC, Rizo VH, Silva-Sousa YT, Almeida LY, Almeida OP, Leon JE. Immunohistochemical evaluation of angiogenesis and tryptase-positive mast cell infiltration in periapical lesions. J Endod 2011;37:1642-1646.

17. Amaral FR, Mateus GC, Bonisson LA, de Andrade BA, Mesquita RA, Horta MC, et al.. Cell proliferation and apoptosis in ameloblastomas and keratocystic odontogenic tumors. Braz Dent J 2012;23:91-96

18. Baumgart CS, Lauxen IS, Sant'anna Filho M, Quadros OF. Epidermal growth factor receptor distribution in pericoronal follicles: relationship with the origin of odontogenic cysts and tumors. Oral Surg Oral Med Oral Pathol Oral Radiol Endod 2007; 103:240-245.

19. Clark P, Marker P, Bastian HL, Krogdahl A. Expression of p53, $\mathrm{Ki}-67$, and EGFR in odontogenic keratocysts before and after decompression. J Oral Pathol Med 2006;35:568-572.

20. Gulkesen KH, Kilicarslan B, Altunbas HA, Karpuzoglu G. EGFR and $\mathrm{p} 53$ expression and proliferative activity in parathyroid adenomas: an immunohistochemical study. APMIS 2001;109:870874.

21. Zhang C, Chang J, Sonoyama W, Shi S, Wang CY. Inhibition of human dental pulp stem cell differentiation by notch signaling. J Dental Res 2008;87:250-255.

22. Lefort K, Mandinova A, Ostano P, Kolev V, Calpini V, Kolfschoten I, et al.. Notch 1 is a p53 target gene involved in human keratinocyte tumor suppression through negative regulation of ROCK1/2 and MRCKalpha kinases. Genes Dev 2007;21:562-577.

23. Massi D, Tarantini F, Franchi A, Paglierani M, Di Serio C, Pellerito $\mathrm{S}$, et al.. Evidence for differential expression of Notch receptors and their ligands in melanocytic nevi and cutaneous malignant melanoma. Mod Pathol 2006;19:246-254

Received April 10, 2012 Accepted August 15, 2012 